\title{
River Environment Conservation Efforts through Development Ecotourism River Tubing Mayangsari to Support Sustainable Development
}

\author{
Fajar $^{1}$, Hartati Sulistyo Rini ${ }^{2}$ \\ \{ajangfajar@mail.unnes.ac.id ${ }^{1}$, hartatisulistyorini@mail.unnes.ac.id ${ }^{2}$ \} \\ ${ }^{1,2}$ Universitas Negeri Semarang, Indonesia
}

\begin{abstract}
Natural environment-friendly tourism is currently growing rapidly. One of them is the Mayangsari River tubing ecotourism managed by the Mayangsari Tourism Awareness Group (Pokdarwis) of Semarang City by utilizing the Kreo River flow. In line with the development of the river tubing ecotourism, the idea of river conservation emerged. This article examines river conservation efforts carried out by Pokdarwis by involving community components, and examines the obstacles faced by Pokdarwis in the process of fostering community awareness of conservation of river environments. This research was conducted in Mayangsari Village, Kalipancur Village, Ngaliyan District, and Semarang City. The subjects in this study were the administrators of Pokdarwis, the River Care Community, the Disaster Prepared Family (KSB), and the community of Mayangsari Village. Data obtained through direct observation and in-depth interviews. Data analysis was carried out with an interactive model qualitative method. The results showed that through this ecotourism came ideas and movements to preserve the river environment. Efforts to clean the river are: making rules and sanctions not to pollute the river, procuring trash bins in each house, providing free toilet assistance for households that do not have latrines, cutting down banana trees around the river which can cause soil to erode easily, do river flow activities to see what problems are around the river, do mutual cooperation to clean the river, and educate the public about the preservation of the river environment. Obstacles in the process of preserving the river environment are: there are still people who defecate in the river, the participation of the community to clean the river is still low, some people outside the Mayangsari village dispose of garbage in the river, and there is no collective agreement on the conservation of the river environment between regions.
\end{abstract}

Keywords: Effort, River Environment Conservation, River Tubing Ecotourism, Sustainable Development.

\section{Introduction}

Tourism activities, especially those based on natural environment, are still interesting for tourists. Tourism based on natural environments such as those in the Bogor Peak and Bandung area has always been a tourist destination on every long holiday. Likewise, in Bali and Raja Ampat Papua's beach tourism is always crowded with domestic and foreign tourists. Naturebased tourism does indeed provide its own sensation for tourists. This offered of natural beauty, cool and fresh natural air is something that tourists are waiting for, especially those 
from urban areas. For the urban community this nature-based tourist attraction is felt to be able to momentarily eliminate fatigue, fatigue, and stress from the routine workplace.

Apparently nature tourism activities do not always have a positive impact on the social, cultural and natural environment. Some studies show that tourism activities actually have a negative impact on the natural environment. Research carried out by the Regional Secretary Elisa Priyanto in the Karimunjawa tourist area shows that natural environment damage was caused by tourism activities that began to be high, the damage included: damage to the coastline, damage to coral reefs, reduced dewandaru trees and kalimasodo for the production of souvenirs, and conversion of land into a commercial place [1]. Other research shows that there are negative effects of coastal tourism activities in Taplau Padang such as the accumulation of garbage around the coast and estuary, coastal pollution, unpleasant odors and standing water [2]. Research conducted by Ferncius Limbong and Sugiono Soetomo in Karimunjawa National Park shows that tourism activities have a negative impact in the form of snorkeling activities that can damage the environment of Karimunjawa National Park, the construction of lodgings results in reduced open land and reduced catchment areas that can be used for clean water supply and can occur natural disasters namely landslides [3].

The negative impact that accompanied the increase in tourist visits seems to be a new problem for managers of tourist attractions and other visitors. Therefore, the government and the public need attention and intervention in minimizing the natural environment due to overexploitation by tourism actors and the importance of educating tourism actors to understand the ethics of travel. This is important so that the attraction of tourist attractions can still be maintained in the long term. From here comes the idea of the concept of tourism which still provides economic benefits but also can still maintain the preservation of the social, cultural and natural environment. The concept of tourism is known as ecotourism. The definition of ecotourism from The International Ecotourism Society cited by Kurniasari et al. Shows that ecotourism is a form of tourist travel to natural areas carried out with the aim of conserving the environment and preserving the lives and welfare of local residents [4]. The concept certainly becomes in line with the development of sustainable tourism and supports the concept of sustainable development. The concept of ecotourism has several principles that show the interrelationships between environmental, social and economic aspects. Eplerwood's ecotourism principles cited by Kurniasari et al are as follows: preventing and overcoming the effects of tourist activities on nature and culture, environmental conservation education, direct income for the region, community participation in planning, community income, and maintaining harmony with nature, environmental carrying capacity, and income opportunities in a large portion of the country [4].

Usually natural tourist attractions popular in the community are managed by the private sector. The developed tourism infrastructure is loaded with large capital; therefore the tour packages offered are also expensive. Investors or large investors deliberately conceptualize tourist attractions with spectacular forms and equip them with luxury hotels or inns to bring great profits. Some such tourist attractions can be found in the tourist areas of Batu, East Java, Bandung, West Java, and in Bali. In the same place, small capitalized tourism actors also get economic benefits. But the value obtained is not as much as investors. Local people get little benefit from trading activities on a small scale, as well as service activities such as being laborers or employees at tourist attractions, becoming parking attendants, and homestay providers for travelers.

Lately, many tourist destinations have emerged that highlight certain characteristics such as nature, culture, social and others where the local community is active in managing the tourist attractions. For example, water tourism in the Klaten area in 2015 has contributed 
greatly to the income of the Ponggok Village Enterprise (BumDes), Polanharjo District, Klaten Regency, as much as Rp. 4.7 billion [5]. Other research shows that through water tourism activities Umbul Ponggok has contributed merchant income of Rp. 1,500,000 - Rp. 3,000,000 from respondents as much as 73\%, while traders who earn more than Rp. 3,000,000 as much as $20 \%$, the rest earn below Rp. 1,500,000 [6]. Another ecotourism that is managed by people who are members of the Tourism Awareness Group (Pokdarwis), namely cave tubing, Goa Pindul. The tourist area of Goa Pindul has provided income for Gunungkidul Regency as much as Rp. 3.6 billion [7]. In addition to contributing economically, this tourism has problems in the management of liquid waste and solid waste from tourism activities, has the risk of disaster and damage to the cave ecosystem because the prone karst area is damaged [7].

The success of Pokdarwis managing natural potential into an ecotourism destination that is beneficial for the community inspires people in various regions to develop their natural potential. One community group that is trying to develop the natural potential of a watershed (DAS) into ecotourism is pokdarwis Mayangsari Water Tubing. Management of the Kreo Watershed starts from the initiative of a number of young people who want to present ecotourism in the midst of urban communities, especially the city of Semarang. The existence of the Kreo River Basin is a natural potential that promises economic benefits to the community. The spirit of Pokdarwis to develop the Mayangsari River tubing ecotourism received the attention and support of the local government. All infrastructure and regulations that support the realization of ecotourism have been provided by the local government. However, to develop this river tubing ecotourism it is not enough to be supported by the sector in fulfilling infrastructure and regional government support alone. It turns out that to complement the development of ecotourism requires the carrying capacity of the environment both physically, socially and culturally.

In order to develop the river tubing ecotourism, a group of young people who are members of the Mayangsari Water Tubing realize that the river as a tourist attraction must be free from all kinds of dirt. The idea was to make a conservation movement around the Kreo River. Thus the Kreo River as a vital ecotourism object must be clean of all garbage and waste to be worthy of being a tourist destination. What steps are taken by a number of young people to carry out conservation movements and their obstacles, this is what becomes interesting to study. The focus is interesting to study because most other researchers pay more attention to aspects of socio-economic impacts (community welfare) from the existence of ecotourism [2] [8]; see the environmental impact of increasing tourist visits [1] - [3]; community participation in managing ecotourism potential [4] [9] [10] [11]. While the research that examines the preservation of the river environment has also been numerous such as for example the conservation of the River Code [12] [13] [14] [15]. The study of river conservation is not related to ecotourism development.

\section{Methods}

This study will use qualitative methods that produce descriptions of those observed [16]. To sharpen the process of data collection and data interpretation, the researchers used a case study approach with a research locus in the Mayangsari, Kalipancur Village, Ngaliyan District, Semarang City [17]. This location was chosen as a research site because in this region there are eco-activities in the form of river tubing that crosses the Kreo watershed. Through this river tubing tourism activity, people are awakened by their awareness to preserve the river environment. In addition, the process of fostering public awareness to participate in the 
preservation of the river environment is not an easy thing. This is due to the transition process of the characteristics of the community from the village which has the image of a slum, a culture of lower social class society known as beggar villages. Data is obtained through observation and interviews conducted in July. Subjects and informants in this study were the Chairperson of Mayangsari Pokdarwis Water Tubing, Chair of the Disaster Preparedness Family (KSB), Chairperson of the River Care Community (KPS), and the community of Mayangsari Village. Field data that has been taken is then analyzed using models of analysis from Miles and Haberman [18].

\section{Result and Discussion}

\subsection{Community Social Characteristics of Mayangsari Village}

Mayangsari village is located in RW 2 Kalipancur Ngalian Village, Semarang City. The location of Mayangsari village is in conflict with the watershed downstream of the Kreo River. The Upper Kreo River is in the hilly area of the slopes of Mount Ungaran. In the upstream part, a dam called the Jatibarang Reservoir has been built which drowns green land from four villages located in Gunungpati District and Mijen District, Semarang City. Before it empties into the Java Sea the Kreo River blends with the Garang River into the West Flood Canal which divides the City of Semarang.

The Mayangsari Village community includes urban communities that have complex social characteristics. Initially this village was a relocation area for residents in the Perbalan area of Semarang City who were affected by great fire. In addition, people in the Kuwasen area of Gunungpati District and the Barutikung community from North Semarang District. The three regions include the suburbs whose social class is low with hard characters. According to the Head of the River Care Community (KPS), the community of Mayangsari Village is considered as a "dump" community.

The face of Mayangsari Village is famous as a scary area. Several criminal cases have occurred in this region, as told by local leaders where homicides occur due to infidelity. Some parents who live in the village are former diggers or thugs in Semarang. At night, people outside are afraid to enter this area. Whereas from the perspective of the Mayangsari Village community, the area they inhabit is safe. According to the Head of the River Care Community, there were no residents who lost their motorbikes even though on the night the vehicle was left in the front of the house.

In the beginning, the socio-economic status of the people in Mayangsari village was low. Low community education has led to the profession occupied by the community mostly as low-paid odd-numbered laborers. Even many among middle-aged women who work as beggars. Therefore, this village was known as the beggar village. Low income is one of the factors behind the condition of the Mayangsari Village settlement. In the past many semipermanent and non-permanent houses were found that occupied the banks of the Kreo River. There are still many houses that do not have toilet facilities, therefore in this village there are public toilets provided by the local government for residents. This village is also a densely populated settlement.

In the period of Indriastuti's leadership as Kalipancur Village Head, the dark face of Mayangsari Village was gradually improved. The Commitment of the Kalipancur Urban Village Head to facilitate the transformation of the community was truly carried out until the end of his term of office. Many urban village programs are planned to change the community 
for the better. Through the thematic kampung program, the Kalipancur village head encouraged and explored the potential of the Mayangsari village community to finally form a thematic snack village. This program has changed the habits of mothers who beg to become people who have a business making snacks. Community training and empowerment related to making various snacks and marketing is often held in this village. In addition, the regional government poured funds for the construction of road infrastructure and provided settlement arrangement assistance. Socially the community continues to be empowered through various activities. Youth are encouraged to actively carry out useful community activities such as Pokdarwis, KSB, KPS and so on. The transformation of the community in Mayangsari Village is still ongoing. One of them is related to the conservation of the environment around the river that supports the development of river tubing ecotourism by utilizing the potential of the Kreo Watershed.

\subsection{River Environmental Conservation Efforts to Support Ecotourism River Tubing}

A tourist area can be a tourist destination because it fulfills important elements that support tourist attraction. This important element is related to providing the needs needed by tourists so that the destination of tourist visits can be fulfilled. As quoted by I Gde Pitana and I Putu G Gayatri in Jacson, the elements that affect a region become tourist destinations include: attractive to tourist, facilities and attractions, geographic location, transport links, political stability, healthy environment and no government restriction [19]. Similarly, a few of young people was initiated the Mayangsari River tubing ecotourism in 2018. The idea of ecotourism that utilizes the Kreo watershed create to Mayangsari Pokdarwis Water Tubing. This Pokdarwis is then a driving force in realizing the ecotourism. The efforts that have been made by Pokdarwis are for example by coordinating with the Balai Besar Sungai (BBWS) and the government of the Kalipancur Sub-District to provide Pokdarwis legality in order to utilize the river for tourism activities. In addition, river tubing facilities and infrastructure continue to be equipped with adding tubing equipment such as tires as buoys, life jackets and helmets for life safety. Construction of facilities and access to tourism continues to be added both through self-help methods and with assistance from the local government. Another planned aspect is to make tour packages with certain rates and facilities that tourists will receive. The Pokdarwis also carried out a promotion strategy through the use of social media such as Instagram and through coordination with the Semarang City Tourism Office.

The efforts that have been made to prepare the ecotourism turned out to be insufficient. There are other challenges faced so that this river tubing ecotourism becomes feasible to become a community tourism destination. The challenge is in the form of pelesatarian environmental efforts around the Kreo River. There is an urgency that must be done why efforts need to be made to preserve the river environment. It is common knowledge that ecotourism is in rural or mountainous areas whose nature is still preserved. Likewise with river tubing ecotourism in some areas that tend to be located in rural or mountainous areas as well as those far from residential areas. Thus the manager of ecotourism in the area at the beginning of its development is not preoccupied with efforts to preserve the natural environment. The rivers that are used as tourist objects are usually clean and free from garbage and the surrounding environment is still beautiful and beautiful.

Unlike the case with river tubing ecotourism developed by Pokdarwis Mayangsari. Kreo watershed that is used for tourism activities is in urban environments. Of course at some point you can find residential areas on the banks of the Kreo River. This is a problem for Pokdarwis, where the river to be crossed by tourists is actually dirty. The problem of the river is due to the 
disposal of household waste. The waste comes from the household bathroom channel which is channeled into the river. Until near 2017 there are still many people in Mayangsari Village who do not have latrines. Therefore there are still many defecation activities that do it in the river. In addition, the absence of waste management in the kampong makes the community use practical search by removing garbage in the river. This further worsened the face of the Kreo River. Such patterns of community activity occur because one of them is caused by the socio-cultural characteristics of the people in Mayangsari Village described above. That kind of environment around the river has caused the Kreo River watershed not to be used for tourism activities.

Based on this situation was born the idea to carry out efforts to preserve the river environment. Pokdarwis Water Tubing Mayangsari, assisted by KPS, KSB, and the community and government institutions became an actor in carrying out the movement to clean up the river from all kinds of garbage that pollutes the river. The things were done to clean the river start from doing the river fringing activities. This activity was carried out by several community groups such as Pokdarwis, KSB and KPS. The activities that can be done are by around along the river which is crossed by tubing. The result of this riverbank is the discovery of problems found in the Kreo River. The follow up of the river alignment is by to clean the river together. This activity is carried out once a month. Clean-up activities of the river include, among others, taking the form of tree trunks or branches around the river, cutting down banana trees that make soil erosion easily and planting trees that can strengthen the soil structure. Tree planting activities are carried out together with students.

Efforts to clean the river are also carried out by picking up trash that is around the river and making regulations prohibiting throwing garbage in the river. These rules Pokdarwis, $\mathrm{KSB}$, KPS are proposed to RT / RW Institutions, District and even those regulations have been submitted to the city government through the relevant agencies to be stipulated as regulations that have clear legal legality. People, who are found littering, then imposed sanctions that are forced. The next step is to create a joint waste management system and the provision of rubbish bins. Before the river tubing tourism activity existed, the community had not yet managed to collect waste collectively. The absence of garbage bins and the reluctance of people to pay for collective waste management services make people throw rubbish in any place, including throwing garbage into the river. Along with the development of ecotourism in this village the community gets free trash bins and gets education about communal waste management.

It is clear that defecation activity in the river does not support river tubing ecotourism. Therefore a public latrine and household latrine procurement program was created. This program is assistance from the government to facilitate people who do not have latrines at home. Apart from the government, free toilet assistance was provided by a doctor in Semarang City. Residents help make latrines in homes where bathrooms are not yet available. This program is strived to change the habits of the people who defecate in the river. Despite the availability of latrines, the KPS chairperson still monitors and advises if there are people who throw garbage into the river or defecate. Another program is the closure of gutters so that the garbage carried by rainwater does not enter the gutter and then into the river. Sewer closure gives the impression of clean Mayangsari Village while minimizing the smell of household waste.

Table1. River Environment Conservation Activities that Support Ecotourism

\begin{tabular}{ccc}
\hline Activity & Implementer & Result \\
\hline Stream the & Pokdarwis, KSB, & Found the problem in the river
\end{tabular}




\begin{tabular}{|c|c|c|}
\hline River & KPS & \\
\hline $\begin{array}{l}\text { Working } \\
\text { together clean } \\
\text { the river }\end{array}$ & $\begin{array}{l}\text { Pokdarwis, KSB, } \\
\text { KPS, citizen }\end{array}$ & $\begin{array}{l}\text { Cutting down banana trees which causes soil erosion easily, } \\
\text { picking up trash in the river }\end{array}$ \\
\hline Planting trees & $\begin{array}{l}\text { Pokdarwis, KSB, } \\
\text { KPS, students }\end{array}$ & Planting hard plants to strengthen the soil around the river \\
\hline Making Rules & $\begin{array}{l}\text { Pokdarwis, KSB, } \\
\text { KPS, Chief of } \\
\text { RT/RW, All the } \\
\text { Citizen }\end{array}$ & $\begin{array}{l}\text { Issued regulations and sanctions so that people do not throw } \\
\text { garbage in the river. Propose these regulations to the relevant } \\
\text { agencies }\end{array}$ \\
\hline $\begin{array}{l}\text { Waste } \\
\text { Management }\end{array}$ & $\begin{array}{l}\text { All the citizen } \\
\text { members }\end{array}$ & $\begin{array}{l}\text { Provide a trash can in each house. Manage collectively collect } \\
\text { waste from citizens through a payment system. }\end{array}$ \\
\hline $\begin{array}{l}\text { Household } \\
\text { Latrines }\end{array}$ & $\begin{array}{l}\text { Pokdarwis, KSB, } \\
\text { KPS, Donatur }\end{array}$ & $\begin{array}{l}\text { Make a public toilet and latrine in the bathroom of the house to } \\
\text { change the habit of defecating in the river }\end{array}$ \\
\hline $\begin{array}{l}\text { Social } \\
\text { Control }\end{array}$ & KSP & $\begin{array}{l}\text { Monitor and advise residents who defecate and defecate in the } \\
\text { river }\end{array}$ \\
\hline $\begin{array}{l}\text { Close the } \\
\text { gutter }\end{array}$ & $\begin{array}{l}\text { Government with } \\
\text { citizen }\end{array}$ & $\begin{array}{l}\text { Close gutters to prevent trash from entering the gutter. Reduces } \\
\text { odors and beautifies the environment }\end{array}$ \\
\hline
\end{tabular}

Efforts to preserve the environment around the river carried out by local communities are a tangible manifestation of sustainable tourism activities. The steps to preserve the river environment are in line with the concept of ecotourism which emphasizes management which combines two environments both physically and culturally. This is as stated by Surya Cipta Ramadhan that managing ecotourism is very important to integrate the components of the biophysical environment (natural quality) and culture (social culture) because it has interdependence and interrelationship in an ecosystem [20]. Thus the purpose of tourism development to improve the economic welfare of the community still considers the balance of ecological values.

\subsection{River Environmental Conservation Constraints}

The hope of being able to develop the realization of ecotourism that is worthy of being a tourist destination is often stuck by several obstacles. Barriers associated with efforts to preserve the river environment with regard to the problems of the community itself. Community participation is an important part that also supports ecotourism development. According to Rifkin et al quoted by Eva Kurniasari, interpreting community participation as community involvement, contributions from the community in the implementation of activities that have been decided, and jointly utilizing the results of the program so that people benefit from the program [4]. The definition provides an overview of how the community should act in a program. Community participation in the development of ecotourism is needed so that tourism activities can be sustainable. Therefore community involvement in ecotourism development planning is important to foster a sense of responsibility, caring and feeling of belonging to the attractions in the area.

The ideal idea is like that, but in practice the expected participation of the community has not yet fully emerged. This fact is also found in the preservation of the river environment in Mayangsari Village. According to the head of the KPS, the Mayangsari village community has not been moved to jointly carry out mutual cooperation activities to clean the river. The characteristics of the community with the type of work as odd jobs and other informal workers make it difficult to manage the time for the community to join in these activities. On the other hand awareness to care for the river environment is also still low. According to the statement 
of the chairman of the KSB, the river clean-up program was even considered by some members of the community to be crazy activities and activists were also considered as crazy people. Work together in community in cleaning the river has not been said to have succeeded in growing community participation in the movement to clean the river environment.

Another difficulties obstacle is changing the habits of people defecating in the river. Mayangsari village has received assistance in facilitating public toilets that can be used by residents of the Kreo River. Through the procurement of public latrines there have actually been efforts to change the habits of people defecating in rivers. Not only that, the environmentally conscious community groups even sought donors from institutions and individuals who wanted to provide free toilet assistance. According to the chairman of the KSP two years ago the Mayangsari village had received assistance from the Koramil which launched a thousand toilet program. In addition there are 110 donors who provide free toilet. The program has been implemented, people who initially did not have latrines have now been able to use it. But in practice there are some people that still had difficult to change the habit of defecating in the river eventhough they have a private latrines. Control carried out by KPS every day often finds some people who defecate on the river. Efforts to educate the public not to defecate in the river have often been done. Perpetrators also often have been reprimanded and advised. The defecation activity should not have been carried out by the community, especially when Pokdarwis had delivered a river-based ecotourism development program. But in reality some people do not want to support the program.

The barriers above indicate the existence of community characters fragmentation. There are a number of people who are enthusiastic and show concern for the river environment by participating in those activities. But there are also those who are apathetic towards the preservation of the river's environment and even doubt their efforts to clean up the river. Until this research is carried out, the negative impact of Mayangsari river tubing ecotourism is more on the issue of community awareness fragmentation on the preservation of the river environment. While social conflicts caused by economic problems or income from the management of tourist areas as happened in some other ecotourism have not been found in Mayangsari river tubing ecotourism. In this part, it certainly can be understood because Mayangsari's water tubing ecotourism activities are not popular yet in the Semarang City community and have not provided large economic benefits yet.

The two obstacles come from within the community itself. In addition to obstacles originating from within, there are also obstacles to the preservation of the river's environment sourced from outside the community. Making some efforts to preserve the river environment by through the caring activities for the river and providing education to minimize river pollution. The obstacle is in the form of the lack of understanding among the people in the Kreo Watershed to jointly carry out the preservation of the river environment. Therefore, there are still people outside of Mayangsari Village who dump their trash and household waste on the Kreo River. If efforts to preserve the river environment are carried out jointly between communities in the area around the river, it will be faster to minimize the pollution of the river environment. According to the explanation of the chairman of the KSB, the people of Mayangsari Village had not disposed of their waste and garbage in the river. However, there were residents from other regions who were caught dumping garbage in the river. The case was then handled in a family manner by bringing together the two leaders of the Rukun Warga (RW) region mediated by the kelurahan. In the end, the synergy of conservation between regions has an important position so that efforts to preserve the river environment are truly carried out in an integrated manner by all communities whose territory is passed through the Kreo Watershed. 


\section{Conclusion}

The development of river tubing ecotourism in Mayangsari village in the end synergized with efforts to escape the river environment. The efforts made to preserve the river environment are through the issuance of regulations and social controls, river cleaning activities, tree planting and the management of household waste and waste. Obstacles in efforts to preserve the river environment are related to the lack of mutual understanding between communities in the area around the river and the difficulty of changing the habit of defecating in the river. The development of ecotourism into a tourist destination that brings material benefits is closely related to social aspects through community participation and physical aspects in the form of escape from the natural environment. In other words economic prosperity will not be achieved without considering the social elements and elements of the physical environment. The relationship between the three systems, social, economic and physical environment inherent in ecotourism activities is in line with sustainable development.

\section{References}

[1] S. E. Priyanto, "Dampak Perkembangan Pariwisata Minat Khusus Snorkling Terhadap Lingkungan: Kasus Destinasi Wisata Karimunjawa," Jurnal Kepariwisataan, vol. 10, no. 3, pp. 13-28, 2009.

[2] Y. R. dan M. Muktialie, "Pengaruh Aktivitas Pariwisata Pantai Taplau Kota Padang Terhadap Ekonomi, Sosial Masyarakat, Dan Lingkungan,” Jurnal Teknik PWK, vol. 3, no. 4, pp. 979-990, 2014.

[3] F. L. dan S. Soetomo, "Dampak Perkembangan Pariwisata Terhadap Lingkungan Taman nasional KLarimunjawa," Jurnal Ruang, vol. 2, no. 1, pp. 351-360, 2014.

[4] E. Kurniasari and E. dan F. T. Rustiadi, "Strategi Pengembangan Ekowisata Melalui Peningkatan Partisipasi Masyarakat, Studi Kasus Komunitas Kelurahan Kalimulya Depok,” Jurnal Manajemen Pembangunan Daerah., vol. 5, no. 2, pp. 32-47, 2013.

[5] S. A. Apriyani, "Strategi Badan Usaha Milik Desa Tirta Mandiri Dalam Pengelolaan Objek Wisata Umbul Ponggok Di Kecamatan Polanharjo Kabupaten Klaten,” Jurnal Adinegara, vol. 5, no. 8, pp. 1-11, 2016.

[6] B. N. Wicaksono, "Tanggapan Masyarakat dan Pengembangan Pariwisata di Desa Ponggok Kecamatan Polanharjo Kabupaten Klaten,” Jurnal Geo Educasia., vol. 8, no. 1, pp. 1-29, 2016.

[7] S. S. A. C. dan; R. F. Agniy, Seri Buku Bunga Rampai "Kepariwisataan, Hidrologi dan Gunungkidul, Kawasan karst Goa Pindul Kabupaten." Yogyakarta: Badan Penerbit Fakultas Geografi (BPFG) Universitas Gadjah Mada, 2016.

[8] N. N. H. dan B. Supriadi, "Potensi Ekowisata dan Kesejahteraan Masyarakat," Jurnal Pesona, vol. 2, no. 2, pp. 1-12, 2017.

[9] D. W. Susyanti and N. Latianingsih, "Potensi Desa Melalui Pariwisata Pedesaan," Jurnal Epigram, vol. 11, no. 1, pp. 65-70, 2014.

[10] M. K. dan L. M. Kolopaking, "Partisipasi Pemuda Desa Dalam Perkembangan Usaha BumDes 'Tirta Mandiri' ( Studi di Desa Ponggok, Kecamatan Polanharjo, Kabupaten Klaten, Provinsi Jawa Tengah)," Jurnal Sains Komunikasi. dan Pengembangan Masyarakat, vol. 2, no. 1, pp. 43-58, 2018.

[11] F. Nazarullail, E. S. Desyanty, and Hardika, "Pemberdayaan Masyarakat Melalui Program Ekowisata 'Lepen Adventure,"' Jurnal Pendidikan Teori, Penelitian. dan Pengembangan, vol. 2, no. 1, pp. 1071-1076, 2017. 
[12] B. Widodo, R. Lupiyanto, and D. Wijaya, "Pengelolaan Kawasan Sungai Code Berbasis Masyarakat," Jurnal Sains dan Teknologi Lingkungan, vol. 2, no. 1, pp. $7-$ 20, 2010.

[13] D. L. Setyowati, P. Hardati, and T. Arsal, "Konservasi Sungai Berbasis Masyarakat Di Desa Lerep DAS Garang Hulu," in Prosiding Seminar Nasional Geografi UMS IX 2018 Restorasi Sungai: Tantangan Dan Solusi Pembangunan Berkelanjutan, 2018, pp. 401-410.

[14] S. Zunariyah, "Upaya Membangun Kemitraan Dalam membangun Pengelolaan Sungai Yang Berwawasan Lingkungan," Dialektika Masyarakat Jurnal Sosiologi, vol. 2, no. 1, pp. 25-46, 2018.

[15] T. T. Fransisca Emilia, Boedi Hendrarto, "Pengelolaan Sumber Daya Alam Berbasis Masyarakat Dalam Upaya Konservasi Daerah Aliran Sungai: Studi Kasus Desa Keseneng, Kecamatan Sumowono, Kabupaten Semarang, Jawa Tengah,” Bonorowo Wetl., vol. 3, no. 32, pp. 73-100, 2013.

[16] L. J. Moleong, Metodologi Penelitian Kualitatif. Bandung: Remaja Rosdakarya, 2004.

[17] R. C. Bogdan and S. K. Biklen, Qualitative Research for Education: An Introduction to Theory and Methods. Massachusetts: Allyn and Bacon Inc., 1982.

[18] M. B. Miles and A. M. Huberman, Analisis Data Kualitatif: Buku Sumber. Tentang Metode-Metode Baru. Jakarta: UI Press, 1992.

[19] I. P. G. G. I Gde Pitana, Sosiologi Pariwisata. Yogyakarta: ANDI, 2005.

[20] S. C. Ramadhan, Pengelolaan Ekowisata Berbasis Goa: Wisata Alam Goa Pindul, Edisi 1. Yogyakarta: Deepublish, 2016. 